\title{
Immature stages of Heraclides thoas thoas (Linnaeus, 1771) (Lepidoptera: Papilionidae): biology and morphology \\ Estágios imaturos de Heraclides thoas thoas (Linnaeus, 1771) (Lepidoptera: Papilionidae): biologia e morfologia
}

\author{
Márlon Breno Costa Santos da Graçal', Ana Lúcia Nunes-Gutjahr"l \\ Instituto Nacional de Pesquisas da Amazônia. Manaus, Amazonas, Brasil \\ "Universidade do Estado do Pará. Belém, Pará, Brasil
}

\begin{abstract}
The morphology and biological aspects of the immature stages of Heraclides thoas thoas (Linnaeus, 1771) (Lepidoptera: Papilionidae) are described. Eggs of $H$. thoas thoas were collected in Belém, Pará, Brazil, and larvae were reared on Piper aduncum L. (Piperales: Piperaceae). Parasitism by Sarcodexia lambens (Wiedemann, 1830) (Diptera: Sarcophagidae) in the pupal stage was observed.
\end{abstract}

Keywords: Amazonia. Chaetotaxy. Life cycle. Morphologic characters. Parasitism.

Resumo: A morfologia e aspectos biológicos dos estágios imaturos de Heraclides thoas thoas (Linnaeus) (Lepidoptera: Papilionidae) são apresentados. Ovos de H. thoas thoas foram coletados em Belém, Pará, Brasil, e as larvas foram criadas com folhas de Piper aduncum L. (Piperaceae). Foi observado parasitismo por Sarcodexia lambens (Wiedemann, 1830) (Diptera: Sarcophagidae) no estágio pupal.

Palavras-chave: Amazônia. Quetotaxia. Ciclo de vida. Caracteres morfológicos. Parasitismo.

GRAÇA, M. B. C. S. \& A. L. NUNES-GUTJAHR, 2014. Immature stages of Heraclides thoas thoas (Linnaeus, 1771) (Lepidoptera: Papilionidae): biology and morphology. Boletim do Museu Paraense Emílio Goeldi. Ciências Naturais 9(3): 519-531.

Autor para correspondência: Márlon Breno Costa Santos da Graça. Instituto Nacional de Pesquisas da Amazônia. Coordenação de Pesquisas em Entomologia. Av. André Araújo, n. 2936 - Petrópolis. Manaus, AM, Brasil. CEP 69067-375 (marlon_lgp@hotmail.com).

Recebido em 24/09/2013

Aprovado em 04/09/2014

Responsabilidade editorial: Marinus S. Hoogmoed

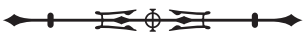




\section{INTRODUCTION}

Butterflies of the Lepidoptera superfamily Papilionoidea are one of the best studied groups of insects from a taxonomic point of view (Gaston, 1991; Kristensen et al., 2007), although data on the diversity of common and widely distributed genera are still below expectations (Ackery, 1987). Studies on morphological characteristics of immature stages of Neotropical butterflies tend to be rare as well as limited to describing the final larval instar and pupa (e.g. Casagrande \& Mielke, 2000, 2005) or the host plants (Dias, 2006). Morphology of immature forms provides potentially diagnostic characters, since larvae have adaptations to habitats and life styles distinct from those of the imago (Stehr, 1987; Dias, 2006). Motta (2003) made use of first instar larval chaetotaxy to construct a phylogeny of the nymphalid subfamily Ithomiinae.

The family Papilionidae contains 560 described species worldwide (Paim \& Di Mare, 2002), of which 129 are found in the Neotropical region and 69 in Brazil (Brown Jr. \& Freitas, 1999). Adults can be recognized by the apical spur on the prothoracic tibia and a frequent extension of $\mathrm{M}_{3}$ vein in the hindwing (Tyler et al., 1994). Also, in swallowtail butterflies, the second anal vein of the forewing is independent of $1 \mathrm{~A}$ and reaches the wing margin (Miller, 1987; Vane-Wright, 2003). Larvae have, in all instars, an osmeterium, a defensive retractile structure located on the prothorax, which releases repellent chemicals (Chattopadhyay, 2011). The genus Heraclides Hübner [1819] has 29 currently recognized species (Häuser et al., 2002). The most recent study on immature Heraclides was published by Leite et al. (2010), who described immature morphology, behaviour and other biological aspects of H. anchisiades capys (Hübner, [1809]).

No detailed studies have been made of the larval chaetotaxy of Heraclides thoas (Linnaeus, 1771) (Figure 1). This species is widely distributed in the Neotropical Region, from Texas to Argentina, including the Caribbean islands of Cuba, Jamaica, Haiti, and Puerto Rico (Rothschild \& Jordan, 1906; Tyler et al.,1994). $H$. thoas thoas can be found in even highly disturbed environments, as pointed out by Paz et al. (2008) and Francini et al. (2011), as well as in flower-visiting studies by Kiill et al. (2000) and Lemes et al. (2008). According to Salgado-Neto (2010), this species feeds on Citrus L., Esenbeckia Kunth, Zanthoxylum L. (Rutaceae) and Piper L. (Piperaceae). Gernaat et al. (2012) report at least 18 species of Rutaceae including Citrus (exotic), 26 species of Piperaceae, and one specie of Araceae (Philodendrum), as

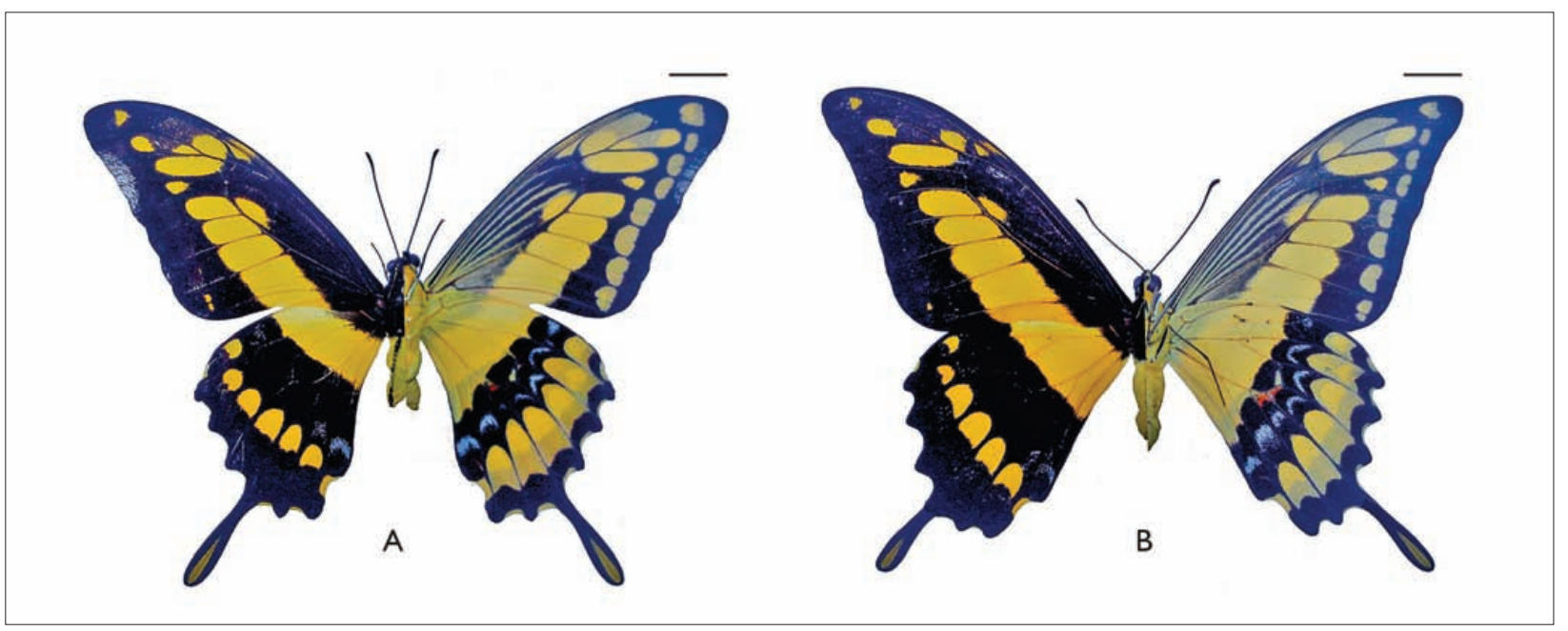

Figure 1. Adults of Heraclides thoas thoas: A) female, left: dorsal view, right: ventral view; B) male, left: dorsal view, right: ventral view. Scale bar $=1 \mathrm{~cm}$. Photos: M. B. C. S. Graça.

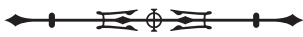


larval host plants. Piper aduncum was the preferred host plant (Moss, 1919; Gernaat et al., 2012). The larva of this species was illustrated by Burmeister (1879, reprinted in Dias, 2006). As Moss (1919) points out, this larva "bears a striking resemblance to a piece of freshly deposited bird's dung". The species' common name in Brazilian Portuguese is 'caixão-de-defunto' (coffin of the dead), a reference to the coffin-like pupa. Gallo et al. (2002) listed the subspecies H. thoas brasiliensis (Rothschild \& Jordan, 1906) as a citriculture plague.

The object of this study is to describe the external morphology and biological aspects of the larvae and pupa of $H$. thoas thoas, with a view to establishing the potential systematic value of these characters, continuing the work of Rothschild \& Jordan (1906), whose revision of New World Papilionidae is basic to the group, Moss (1919), who reared and illustrated the species from Belém, and Tyler et al. (1994), who reviewed the juvenile and adult characters of American swallowtails.

\section{MATERIAL AND METHODS}

\section{EGGS}

Eggs of $H$. thoas thoas $(n=37)$ were collected in three locations in Belém, Pará, Brazil. All eggs were on leaves of Piper aduncum L. (Piperaceae), locally known as 'pimentade-macaco' ('monkey-pepper').

\section{LARVAL REARING}

After collection, all eggs were placed individually in $500 \mathrm{ml}$ beakers with moistened cotton and fresh leaves. The leaves and cotton were changed daily, and the containers were cleaned. Humidity and predators such as ants were controlled by partially immersing the beakers in water. All beakers were left inside an insectary $(1 \times 3 \times 3 \mathrm{~m})$, the walls of which were made of net that permitted the entrance of small insects. Natural conditions of photoperiod, temperature, and precipitation prevailed. During egg and larval development, the rearing containers were closed at the top by netting. After pupae had formed, the netting was removed to allow winged adults to fly.

\section{DESCRIPTION}

After each molt, head capsules were kept dry inside plastic micro-vials for measurement. Three specimens of each instar were killed 24 hours after molting or hatching, the time needed to extend the cuticle, by plunging them in boiling water. Storage was in vials with ethyl alcohol (70\%). Drawings were made with a stereomicroscope with camera lucida. In order to better illustrate some structures, photographs were made with a Leica stereomicroscope model M165C and attached digital camera model DFC420. Digital images with overlapping partial focus were combined using Leica Application Suite V3.4.1. (version 2009) for the final composite photographs.

For chaetotaxy, first instar larvae were clarified in $10 \%$ potassium hydroxide $(\mathrm{KOH})$ for 20 minutes. Specimens were washed with distilled water and placed in glycerin for observations under a stereomicroscope.

Following Leite et al. (2010), described morphological structures are: 1) Larvae - head appendages and sutures, tegument colour pattern, pronotal and anal shields, thoracic and abdominal legs and chaetotaxy of the head, thorax and abdomen; 2) Pupae - colour and texture of the tegument, position and shape of head, eyes, antennae and mouthparts, position of legs and wings, spiracles, visible genitalia and cremaster. Terminology used in chaetotaxy follows Dias (2006).

All voucher material is housed at the Biological Collection of the Pará State University, Brazil.

\section{MORPHOMETRICS}

Measurements for morphometry were made with a micrometric eyepiece. For larvae, three measures were taken: 1) height of head capsule in frontal view, from top of the epicranium to the apex of mandible; 2) width of head capsule in frontal view, between the most external stemmata (as in Freitas, 2007); and 3) length of body from 
head to posterior margin of tenth segment, in dorsal view. For pupae, the length of body was measured from vertex top to posterior margin of tenth segment, in ventral view.

\section{RESULTS}

\section{BIOLOGY}

The mortality rate of the reared larvae was $10.8 \%$, with the death of one egg, two larvae, and one pupa. The first meal of the larva after hatching is the orange substance covering the egg and the corion. After each molt, second, third, fourth and fifth instar larvae eat their exuviae with the exception of the head capsule, whose presence was proof of ecdysis. Newly molted larval heads are yellowish, mandibles are light-brown, stemmata are dark-brown, thoracic legs are translucent (except the tarsal claw), and prothoracic shield is olive. After about one hour, these structures acquire their colour pattern. Average duration of the immature stages is 32 days on Piper aduncum: 17 days as a larva, between this one day as prepupa, and 15 days as a pupa.

\section{FIRST INSTAR LARVA (FIGURE 2A)}

Body: Average length of body 5,4 mm (range: 4,6-5,9 mm).

Head: Average height of head capsule 0,6 $\mathrm{mm}$ (range: 0,6-0,7 mm). Average width of head capsule $0,7 \mathrm{~mm}$ (range: 0,6-0,7 mm). Head round and dark brown, no ornaments. Epicranial suture light-brown, dividing head laterally and delimiting front. Beige bands marking the adfrons. Most setae located on epicranium. Band-shaped transverse clypeus below the front, boarded inferiorly by a membranous anteclypeus. Labrum with two lobes, partly covering the mandibles, which are strongly sclerotized especially on their internal margin. Six stemmata located laterally, stemma one slightly larger than the others. Stemmata 1, 2, 3, 4 and 6 in semicircle, while 5 is more ventrally located near antennal base. Light brown stain posterior to stemmata semicircle. Antennal base in conical membranous socket, formed by three segments, the last containing a terminal setae.
Thorax: Semi rectangular-shaped prothoracic shield, coloured grey. T1 has three pairs of scoli with setae: two pairs on pronotum and other on pleura, all of them light brown. Osmeterium black. T2 and T3 with two dorsal pairs of scoli and another one on pleura. On metathorax, the most dorsal pair of scoli slightly anterior to the other ones. Thorax tegument light brown in T1, and black with light brown stains in T2 and T3. Thoracic legs formed by coxa, trochanter, femur, tibia and tarsus with single tarsal claw.

Abdomen: Dark-brown tegument both dorsally and ventrally. Abdominal segments with a pair of dorsal scoli, dark-brown in A1-A3 and A5-A7, light brown in A4, A8 and $A 9+A 10$. White patch on $A 4$ and part of the pleura of $A 3$. Dark-brown anal shield. Crochets of abdominal legs A3-A6 organized in uniordinal transverse bands, while those of A10 organized in uniordinal lateral penellipse. Average duration of this instar: 2,7 days (range: 2-3 days).

\section{HEAD CHAETOTAXY (FIGURES 3A-3B)}

Twenty pairs of primary setae, not considering those from the labrum. Clypeal group (C): C2 bigger than C1 and located more laterally. Frontal group (F): Single seta, F1 on the lower portion of frons. Puncture Fa adjacent to F1, mesal to it. Adfrontal group (Af): Af2 near the fork of epicranial suture. Af1 ventral to Af2. Afa puncture not detected. Anterior group (A): A1 anterodorsal to antenna base, between adfrons and stemmata 3 and 4. A2 anterodorsal to $A 1$. A3 posterior to $A 2$, dorsal to stemma 2. Aa puncture not detected. Stemmal group (S): S1 inside the stemmata semicircle, posterior to stemma 3. S2 dorsal to stemma 1. S3 posterodorsal to stemma 6. Sa puncture not identified and Sb puncture anterodorsal to stemma 4. Substemmal group (Ss): Ss1 posterior to stemma 4. Ss2 posteroventral to stemma 6. Ss3 posterodorsal to Ss2. Lateral group (L): single seta, L1 posterodorsal to S2. La puncture posterodorsal to L1. Posterior group (P): P1 anterodorsal to A3. P2 between P1 and L1. Pa puncture posterior to $\mathrm{P} 2$. Pb puncture not detected. Microdorsal group (Md): Md1 posterodorsal to Af2. Md2 anterodorsal to Md1. Md3 dorsal to Md1. Mda puncture posterodorsal to Md3. 


\section{THORAX CHAETOTAXY (FIGURE 3C)}

Prothorax: $\mathrm{Xd1}$ posterior to prothoracic shield and $X \mathrm{~d} 2$ ventral to $X \mathrm{~d} 1$, arising from a chalaza and a scolus respectively. D1 posterodorsal to $\mathrm{Xd1}$ growing from chalaza and D2, on scolus, ventral to D1. L1 and L2 arising from the same scolus, ventral to $\mathrm{Xd} 2$ and anterior to the prothoracic spiracle (Sp). SV1 and SV2 located on verruca, posteroventral to lateral group. SV1 dorsal to SV2.

Mesothorax and metathorax: D1 and D2 dorsally located, on chalaza and scolus, respectively, D2 being posteroventral to D1. Subdorsal setae (SD1 and SD2) group arising from a single scolus, posteroventral to D2 in mesothorax, and ventral to D2 in metathorax. L1 and L2 ventral to subdorsal setae, arising from a single verruca. SV1 and SV2 ventral to lateral group, also growing from the same verruca.

\section{ABDOMEN CHAETOTAXY (FIGURE 3D)}

A1-A2: D1 arising from chalaza, on the anterior portion of notum. D2 growing from scolus, posteroventral to D1. SD1 and SD2, on the same verruca, ventral to $\mathrm{D} 1$ and dorsal to the spiracle. L1 and L2 arising from a verruca located posteroventral to SD group. SV1 on a verruca ventral to the spiracle and SV2 ventral to SV1, also growing from verruca. One microventral setae on chalazae (MV1), posterior to SV2. A single ventral setae (V1), ventral to SV2.

A3-A4: Dorsal and subdorsal group with same distribution seen on previous abdominal segments. Both setae of lateral group ( $L 1, L 2)$ arise from a chalaza instead, posteroventral to spiracle. Supraventral group (SV1, SV2), which setae are located altogether on a single verruca, right below the spiracle. MV1 on chalaza posteroventral to SV2, MV2 on verruca anterior to MV1, and MV3 on chalaza anterior to MV2.

A5-A6: Same distribution observed in the third segment, with the exception of the microventral group, whose setae MV2 grows from a chalaza. Seta L3 was not observed on A6.
A7: Same distribution observed in fifth and sixth segments, with the exception of ventral group, whose seta $\mathrm{V} 1$ is present, anteroventral to MV1.

A8: Same distribution observed in seventh segment, with the exception of lateral group, whose setae L1 and L2 grow from a verruca, and seta MV1 is absent.

A9+A10: in A9 region, dorsal group like previous segments. SD1 anteroventral to D2, arising from chalaza. L1 on verruca, posteroventral to SD1, and SV1 also on chalaza, ventral to L1. In A10 region, dorsal and subdorsal groups arising from chalazae on the anal plate. D1 and SD1 are on the anterior margin, SD1 being ventral to D1. D2 is posterior to SD1 and SD2 anteroventral to D2.

\section{SECOND INSTAR LARVA (FIGURE 2B)}

Body: Average length of body: 10,8 mm (range: 10,3-11,3 mm).

Head: Average height of head capsule: 1,2 mm (range: 1,1-1,3 mm). Average width of head capsule: 1,3 mm (range: 1,2-1,3 mm). Head capsule brown. Light-brown epicranial suture. Beige band posterior to stemmata semicircle and another marking the adfrons.

Thorax: Bicoloured osmeterium: basal region dark-orange and distal region dark-brown. Prothoracic shield light-brown. Scoli similar to the first instar, though shorter. Tegument colour begins to show a mosaic pattern, resembling bird excrement, with light-brown stains scattered in a dark-brown matrix. Grey tegument on ventral surface.

Abdomen: Also possesses the mosaic colour pattern, but with two large stains: a white one covering part of A2-A4 and small part of A5, and a yellowish one covering part of $A 7$ and $A 9+A 10$ and all $A 8$. A1 scoli as in metathorax. A2-A7 scoli smaller than in A1, those of $A 5$ and A6 being the shortest. In eighth and final segment scoli are protuberant still, $A 9+A 10$ ones as long as the prothorax ones. Ventral region of $\mathrm{A} 1$ and $\mathrm{A} 2$ grey, as from $\mathrm{A} 3$ it begins to lighten the grey scale. Anal shield light-brown. Crochets of abdominal legs A3-A6 organized as in the previous instar,

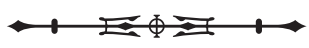


while those of $\mathrm{A} 10$ organized in biordinal lateral penellipse. Average duration of this instar: 2,3 days (range: 2-3 days).

\section{THIRD INSTAR LARVA (FIGURE 2C)}

Body: Average length of body: 16,3 mm (range: 16,0-16,7 mm).

Head: Average height of head capsule: 1,3 mm (range: 1,3-1,4 mm). Average width of head capsule: 1,9 mm (range: 1,8-1,9 mm). Head brown and light-brown epicranial suture.

Thorax: tegument colour as in the previous instar, though light-brown stains are bolder. Light-brown prothoracic shield. Bicoloured osmeterium: basal region light-orange and distal region light-brown. Scoli shorter than those of the previous instar, however those of T1 still prominent.

Abdomen: Light-brown stain on A4 and A5 terga. Abdominal legs basically white, with few grey stains. A9+10 scoli prominent and dark-grey anal plate. Crochets of abdominal legs A3-A6 organized in triordinal transverse bands, while those of $\mathrm{A} 10$ organized in triordinal lateral penellipse. Average duration of this instar: 2,7 days (2-4 days).

\section{FOURTH INSTAR LARVA (FIGURE 2D)}

Body: Average length of body: 27,5 mm (range: 25,4-30,1 mm).

Head: Average height of head capsule: 2,2 mm (range: 2,1-2,4 $\mathrm{mm}$ ). Average width of head capsule: 2,5 mm (range: 2,4-2,7 mm). Beige band posterior to stemmata semicircle. Epicranial suture as in previous instar.

Thorax: Osmeterium dark-orange. White band extending from the base of the osmeterium towards the metapleuron. Dark-brown prothoracic shield, divided in two halves by a longitudinal white line.

Abdomen: Tegument as in previous instar. Anal plate dark-grey. Crochets of abdominal legs A3-A6 organized in triordinal mesoseries and uniordinal lateroseries, while those of A10 organized in triordinal lateral penellipse. Average duration of this instar: 3,6 days (3-6 days).

\section{FIFTH INSTAR LARVA (FIGURES 2E-2F, 4A-4B)}

Body: Average length of body: 46,5 mm (range: 45,9-47,0 mm).

Head: Average height of head capsule: 4,1 mm (range: 4,1-4,2 mm). Average width of head capsule: 4,2 mm (range: 4,1-4,4 mm). Head brown. Epicranial suture covered by a white line until it reaches the adfronts, which are boarded by the fork of this line. Stemmata 1 and 4 slightly larger than the others.

Thorax: Tegument brown but with a somewhat olive-green shade. Osmeterium orange. Prothoracic shield and thorax tegument as in previous instar. Scoli are now replaced by white circles and little lilac spots. Lateral thoracic white band remains.

Abdomen: Abdomen tegument, anal plate and crochets disposition as in previous instar. It is possible to see the pulsation of the dorsal blood vessel through A2, $A 3$ and $A 8$ terga. Average duration of this instar: 6,0 days (range: 5-8 days).

\section{PUPA (FIGURES 2G-2I, 4C-4F, 5A-5B)}

Adectic, succint, obtect. Elongated body, narrowing towards the cremaster. Tegument notably wrinkly, with irregular projections resembling a tree twig. Pupae have a colour pattern dimorphism: one is a brown-green mosaic, and the other is entirely brown. In the first one, wings, thorax, pleural and sternal surfaces of abdomen green. Flattened vertex, divided into two horn-like structures by a $U$-shaped sulcus. Rounded mandibles, elevated clypeus, hexagon-shaped labrum between mandibles and below the clypeus. Galea as long as the hindwings, reaching the fifth abdominal segment. Antennae located between the legs and the forewings. In ventral view, only fore and mesolegs visible, hind legs hidden by wings. Fore legs with two protuberances, one medial and another apical. Mesolegs with a single apical protuberance. Forewings cover great part of hindwings, so only the wing tips are visible. Abdomen with 10 visible segments, first three visible only in dorsal view. Abdominal spiracles are elliptic, visible from $A 2$ to $A 8$, the last one being the smallest. 

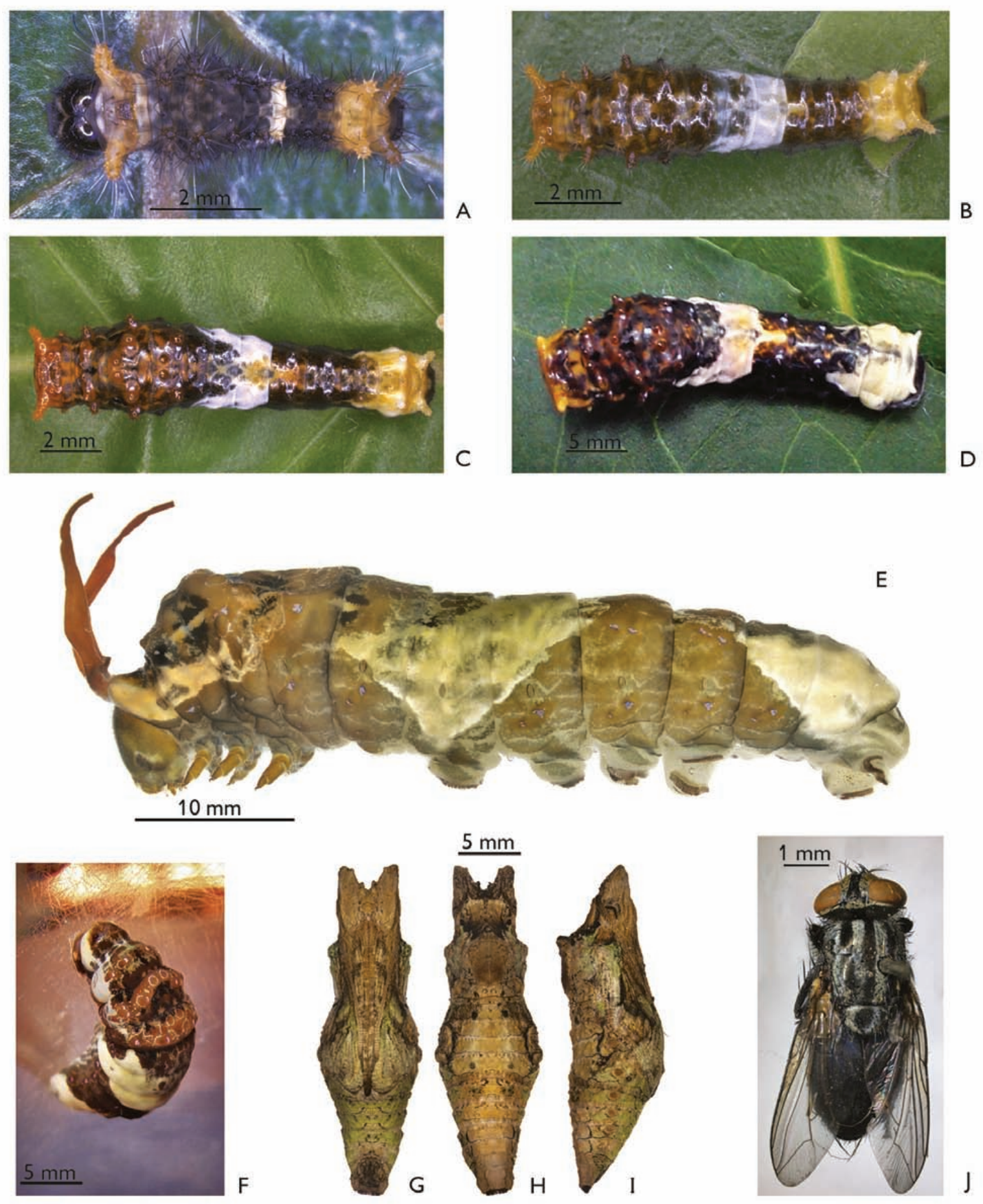

Figure 2. Immature development of Heraclides thoas thoas: A) first instar; B) second instar; C) third instar; D) fourth instar; E) fifth instar; F) prepupa; G) pupa, ventral view; H) pupa, dorsal view; I) pupa, lateral view; J) Sarcodexia lambens, a parasitoid of pupae of $H$. thoas thoas. Photos: M. B. C. S. Graça \& J. Nascimento.

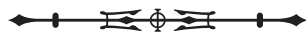




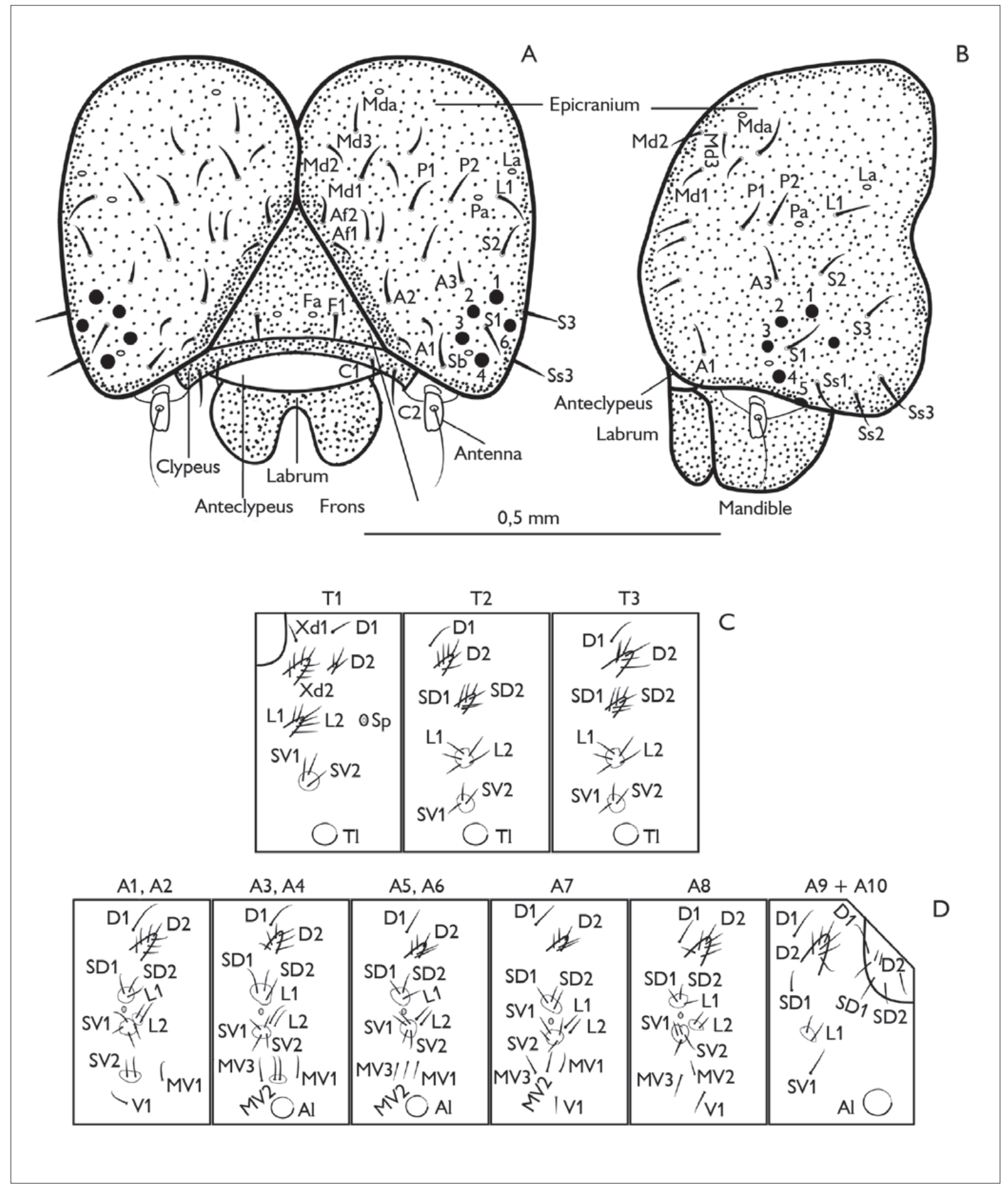

Figure 3. Chaetotaxy of Heraclides thoas thoas: A) head chaetotaxy, frontal view; B) head chaetotaxy, lateral view; C) thorax chaetotaxy; D) abdomen chaetotaxy. Legends: $\mathrm{Sp}=$ spiracle; $\mathrm{Tl}(1-3)=$ thoracic legs; $\mathrm{Al}(3-6,10)=$ abdominal legs.

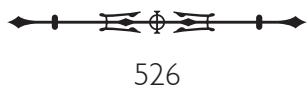



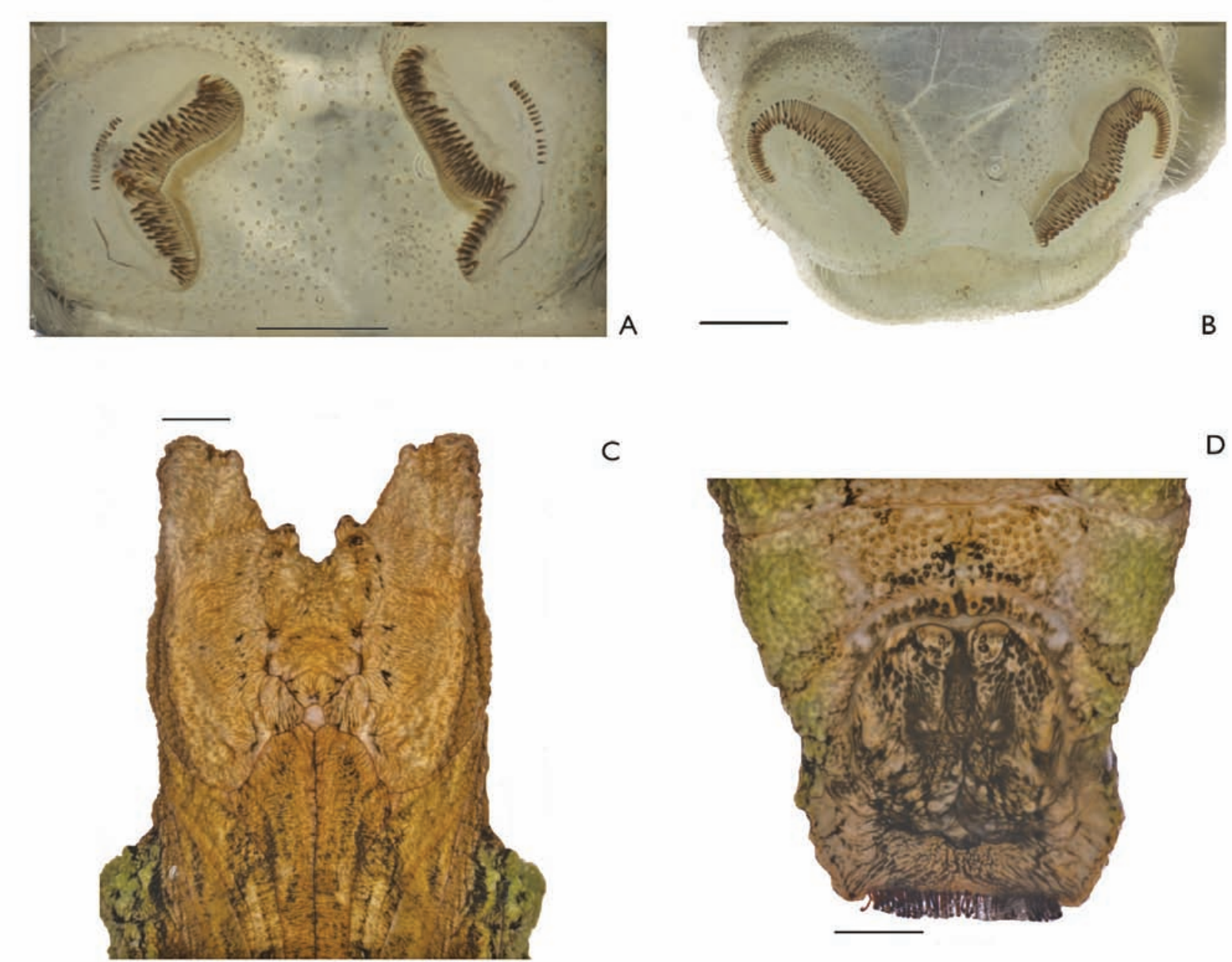

C

D

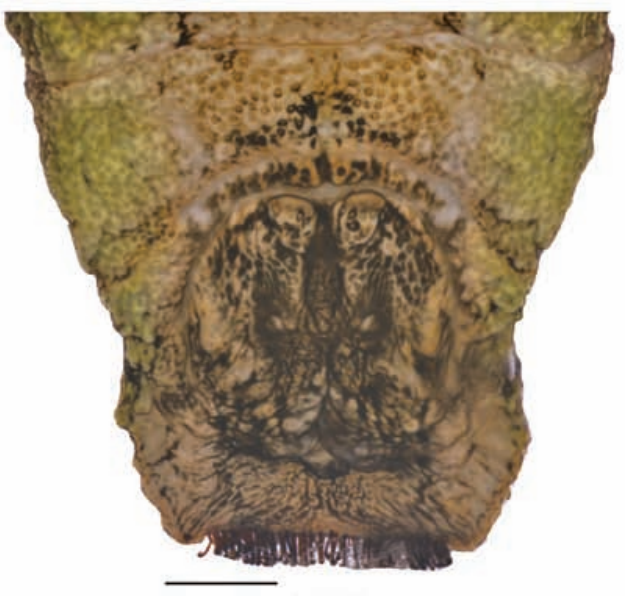

E

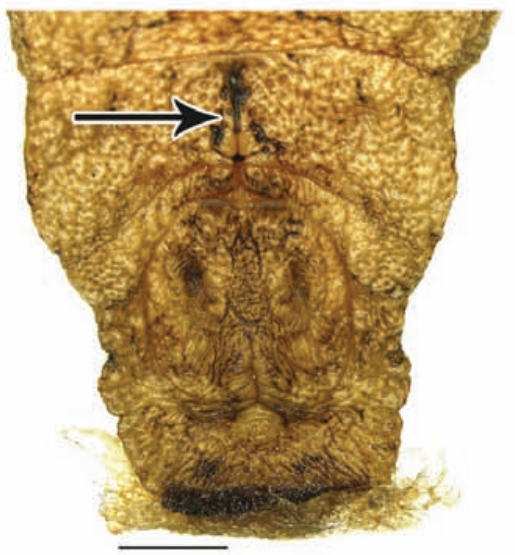

$\mathbf{F}$

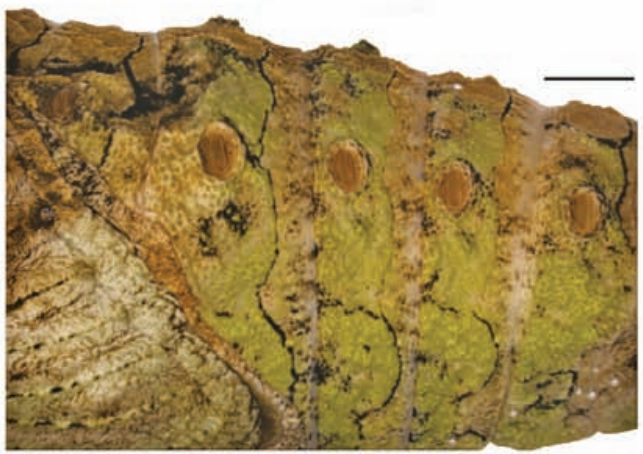

Figure 4. Morphologic structures of Heraclides thoas thoas with potential systematic value. A) Crochets of abdominal leg A4 (fifth instar larva); B) crochets of abdominal leg A10 (fifth instar larva); C) head of pupa, ventral view; D) eighth to tenth sterna of male pupa; E) lateral view of green-brown mosaic tegument of pupa, showing the wrinkly cuticle and spiracles; F) eighth to tenth sterna of female pupa, highlighting the median sulcus. Scale bar $=1 \mathrm{~mm}$. Photos: M. B. C. S. Graça \& J. Nascimento.

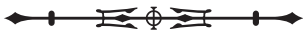




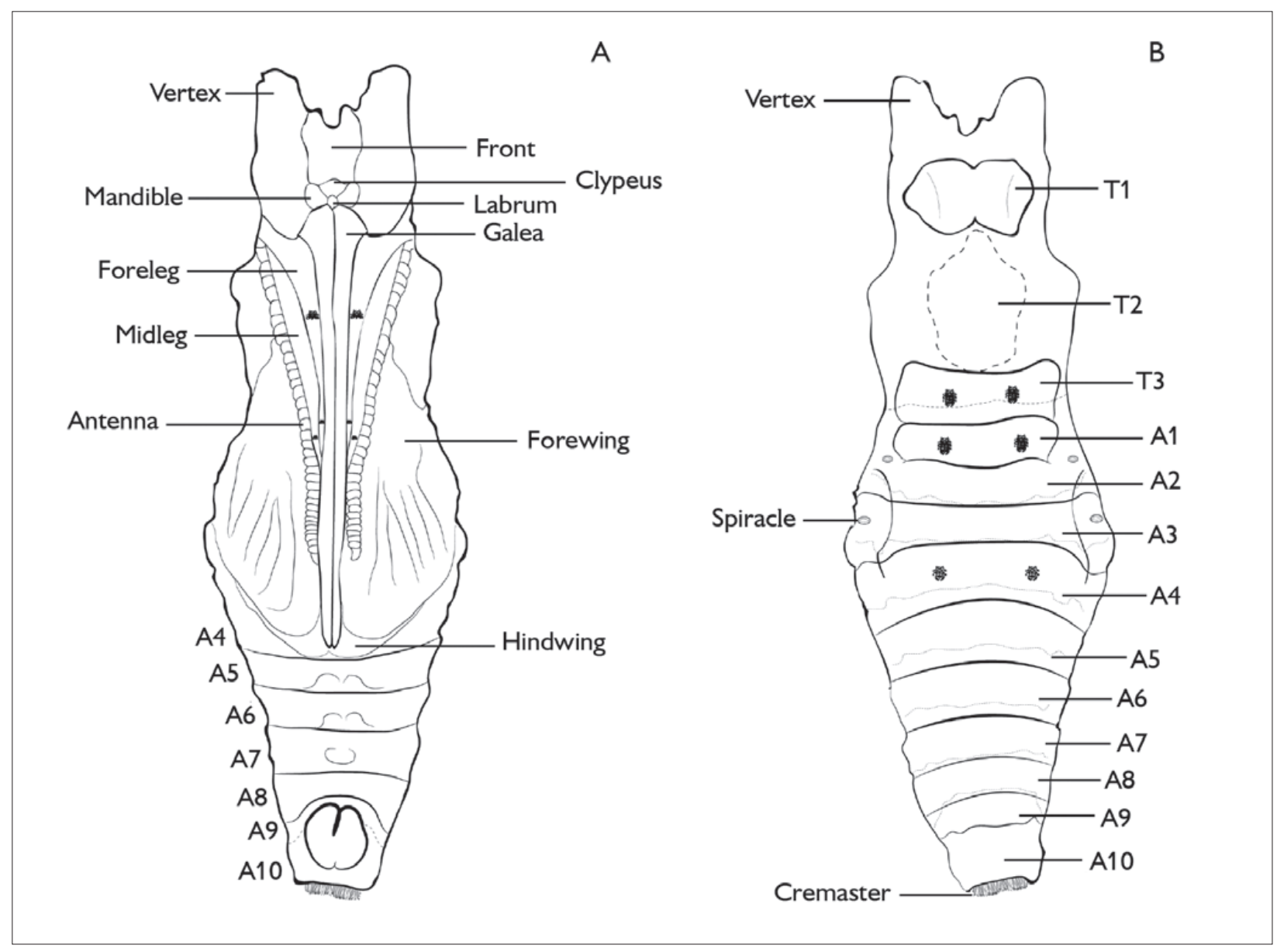

Figure 5. Scheme of pupa external morphology. A) Ventral view; B) dorsal view. Legends: $T(1-3)=$ thorax segments; $A(1-10)=$ abdominal segments.

In dorsal view, $\mathrm{A} 1$ without protuberance and with a pair of black stains. A pair of stains also seen in the metathorax and A4. Very conspicuous depression extending from A2 to A4. Sex distinction through observation of the eighth and ninth sterna. Females with a longitudinal middle sulcus, while males lack it. Cremaster undivided with brown hooks. Average length of body in both sexes: 34,4 mm (range: 33,8-35,1 mm). Average duration of this instar: 14,6 days (14-16 days).

\section{PARASITISM}

During rearing, one pupa was killed by parasitoids. As a sign of the process of parasitism, we could see reddening and softening of the pupa cuticle. Ten days after the expected emergence date, the chrysalis was broken open and detached from the supporting substrate by three final instar larvae of Sarcophagidae (Diptera) that were kept in a Petri plate until they pupated the following day. After six days, adults emerged and were identified as Sarcodexia lambens (Wiedemann, 1830) (Figure 2J).

\section{DISCUSSION}

As for the behaviour of first instar larvae that feed on the orange substance that covers the corium and the corium itself, Leite et al. (2010) suggested that it may influence the development of a sixth larval instar in Heraclides 
anchisiades capys. This conclusion cannot be applied for Heraclides thoas thoas, since no sixth stadium was found in any individual. Xiushan et al. (2006), in their paper on the swallowtail Byasa impediens (Seitz, 1907), stated that an extra larval instar might be associated with climate conditions along the year.

Information about life history could be elicited from observations in the field during collection of eggs. Females lay eggs separately, one per leaf. After hatching, larvae remain solitary, as opposed to $H$. anchisiades capys (Hübner, [1809]) that shows gregarious behavior, according to Leite et al. (2010).

The fact that larvae feed on their previous instar exuviae has been observed by other studies (Tigvatnanont, 1995; Leite et al., 2010) for other species of Papilionidae. According to Panizzi \& Parra (1991), this behaviour may replace the loss of energy during the molting process, when a great part of larval total biomass (around 20\%) might be lost.

As a result of the comparison with similar studies that presented the chaetotaxy of immature Papilionoidea (e.g. Paim et al., 2004; Kaminski et al., 2008; Specht \& Paluch, 2009; Leite et al., 2010, 2012; Dias et al., 2010), we could imply that the number of cephalic setae may have taxonomic importance in categories above the species level, like genus or family, and the disposition of them may separate species. Thorax and abdomen chaetotaxy may have systematic value at the species level as well. This hypothesis may be tested with the development of more studies in the immature morphology of the remaining species of Heraclides and Papilionidae as a whole.

As larval development happens, scoli gradually decrease in height, so the first instar individuals possess the highest ones and the fifth instar, the shortest ones. Leite et al. (2010) found the exact opposite for $H$. anchisiades capys. In pupae morphology, two characters clearly differ from those of $H$. anchisiades capys: (1) $H$. thoas thoas has an undivided cremaster, whereas in $H$. anchisiades capys it is divided, and $(2) H$. thoas thoas has a $U$-shaped depression on the vertex, while $H$. anchisiades capys lacks a marked depression. Pupae of $\mathrm{H}$. thoas also showed different colour patterns. For Papilioninae, this character can be influenced by the characteristics of the pupation site or photoperiod experienced by larvae (Stefanescu, 2004). However, all pupae observed in our study $(n=18)$ chose to enter the pupal stage on the transparent cage wall, thus not responding to site distinction. Data about photoperiod were not recorded, but should be recorded in future research.

Parasitism in immature stages of subspecies of $H$. thoas has been reported to occur by Hymenoptera: Glyptapanteles sp. (Braconidae) (Gil Santana \& Marques, 2006), Pteromalus caridei Brèthes, 1913 (Pteromalidae), Hadranotus sp. (Scelionidae), Brachymeria ovata (Say, 1824) (Chalcididae) (Silva et al., 1968) and Trichogramma pretiosum Riley, 1879 (Trichogrammatidae) (Zucchi et al., 2010); and Diptera: Lespesia rileyi (Williston, 1889) (Tachinidae) (Arnaud Jr., 1978; O'Hara \& Wood, 2004). Hence, the parasitism by Sarcodexia lambens (Diptera: Sarcophagidae) is a new record.

We point out some characters that could have a taxonomic value, because of the difference seen in comparison with other Papilionoidea. They are head, thorax and abdomen chaetotaxy, colour pattern, stemmata size, scoli occurrence and disposition of the crochets for larvae, as well as the cremaster and the vertex structure for pupae.

\section{ACKNOWLEDGEMENTS}

We thank Professor Jacques Jaufrett, owner of the Klagesi Reserve in Santo Antônio do Tauá, Pará, for identifying the butterfly species and for orientation in the field. In particular, Dr. William Leslie Overal for his contribution and suggestions. We are grateful to Dr. Fernando Carvalho for identifying the Diptera Sarcophagidae. We also thank the Museu Paraense Emílio Goeldi (MPEG), in the person of Dr. Orlando Tobias Silveira, and Coordenação de Aperfeiçoamento de Pessoal de Nível Superior (CAPES) pro-Equipamentos Neusa Hamada/Conselho Nacional de Desenvolvimento Científico e Tecnológico (CNPq) for providing photographic 
equipment. Jeane Nascimento, Patrik Barcelos and Rafael Sovano helped with the photographs. We ultimately thank three anonymous referees whose inputs improved an earlier version of the manuscript.

\section{REFERENCES}

ACKERY, P. R., 1987. The danaid genus Tellervo (Lepidoptera, Nymphalidae): a cladistic approach. Zoological Journal of the Linnean Society 89(3): 203-274.

ARNAUD JR., P. H., 1978. A host-parasite catalog of North American Tachinidae (Diptera): 1-860. United States Department of Agriculture, Washington.

BROWN JR., K. S. \& A. V. L. FREITAS, 1999. Lepidoptera. In: C. R. F. BRANDÃO \& E. M. CANCELLO (Eds.): Biodiversidade do estado de São Paulo, Brasil: síntese do conhecimento ao final do século $X X$. 5. Invertebrados terrestres: 225-243. FAPESP, São Paulo.

BURMEISTER, $H_{\text {., }}$ 1879. Description physique de la République Argentine d'après des observations personelles et étrangeres. 5 . Lépidoptères. 2. Partie: 1-60. P. E. Coni, Buenos Aires.

CASAGRANDE, M. M. \& O. H. H. MIELKE, 2000. Larva de quinto estádio e pupa de Caligo martia (Godart) (Lepidoptera: Nymphalidae, Brassolinae). Revista Brasileira de Zoologia 17(1): 75-79.

CASAGRANDE, M. M. \& O. H. H. MIELKE, 2005. Larva de quinto estádio e pupa de Opsiphanes quiteria meridionalis Staudinger (Lepidoptera, Nymphalidae, Brassolinae). Revista Brasileira de Entomologia 49(3): 421-424.

CHATTOPADHYAY, ., 2011. The structure and defensive efficacy of glandular secretion of the larval osmeterium in Graphium agamemnon agamemnon Linnaeus, 1758 (Lepidoptera: Papilionidae). Turkish Journal of Zoology 35(2): 245-254.

DIAS, F. M. S., M. M. CASAGRANDE \& O. H. H. MIELKE, 2010. Aspectos biológicos e morfologia externa dos imaturos de Memphis moruus stheno (Prittwitz) (Lepidoptera: Nymphalidae). Neotropical Entomology 39(3): 400-413.

DIAS, M. M., 2006. Lepidoptera. In: C. COSTA, S. IDE \& C. E. SIMONKA (Eds.): Insetos imaturos: metamorfose e identificação: 175-204. Holos, Ribeirão Preto.

FRANCINI, R. B., M. DUARTE, O. H. H. MIELKE, A. CALDAS \& A. V. L. FREITAS, 2011. Butterflies (Lepidoptera, Papilionoidea and Hesperioidea) of the "Baixada Santista" region, coastal São Paulo, southeastern Brazil. Revista Brasileira de Entomologia 55(1): 55-68.

FREITAS, A. V. L., 2007. A new species of Moneuptychia Forster (Lepidoptera: Satyrinae, Euptychiina) from the highlands of southeastern Brazil. Neotropical Entomology 36(6): 919-925.
GALLO, D., O. NAKANO, S. SILVEIRA NETO, R. P. L. CARVALHO, G. C. BAPTISTA, E. BERTI FILHO, J. R. P. PARRA, R. A. ZUCCHI, S. B. ALVES, J. D. VENDRAMIM, L. C. MARCHINI, J. R. S. LOPES \& C. OMOTO, 2002. Entomologia agrícola: 1-920. Fundação de Estudos Agrários Luiz de Queiroz, Piracicaba.

GASTON, K. J., 1991. The magnitude of global insect species richness. Conservation Biology 5(3): 283-296.

GERNAAT, H. B. P. E., B. G. BECKLES \& T. VAN ANDEL, 2012. Butterflies of Suriname: a natural history: 1-680. KIT Publishers, Amsterdam.

GIL SANTANA, H. R. \& O. M. MARQUES, 2006. Parasitoidismo de Glyptapanteles sp. (Hymenoptera: Braconidae) sobre Heraclides thoas brasiliensis (Rotchschild \& Jordan) (Lepidoptera: Papilionidae). Magistra 18(1): 52-53.

HÄUSER, C. L., R. DE JONG, G. LAMAS, R. K. ROBBINS, C. SMITH \& R. I. VANE-WRIGHT, 2002. Papilionidae - revised GloBIS/GART species checklist ( $\left.2^{\text {nd }} \mathrm{draft}\right)$. Available at: < http:// www.insects-online.de/frames/papilio.htm>. Accessed on: 29 September 2011.

KAMINSKI, L. A., R. DELL'ERBA \& G. R. P. MOREIRA, 2008. Morfologia externa dos estágios imaturos de heliconíneos neotropicais: VI. Dione moneta moneta Hübner (Lepidoptera, Nymphalidae, Heliconiinae). Revista Brasileira de Entomologia 52(1): 13-23

KIILL, L. H. P., F. N. P. HAJI \& P. C. F. LIMA, 2000. Visitantes florais de plantas invasoras de áreas com fruteiras irrigadas. Scientia Agricola 57(3): 575-580.

KRISTENSEN, N. P., M. J. SCOBLE \& O. KARSHOLT, 2007. Lepidoptera phylogeny and systematics: the state of inventorying moth and butterfly diversity. Zootaxa 1668: 699-747.

LEITE, L. A. R., M. M. CASAGRANDE \& O. H. H. MIELKE, 2010 Morfologia, comportamento, parasitismo e mecanismos de defesa dos imaturos de Heraclides anchisiades capys (Hübner) (Lepidoptera, Papilionidae). Revista Brasileira de Entomologia 54(2): 277-287.

LEITE, L. A. R., M. M. CASAGRANDE, O. H. H. MIELKE \& A. V. L. FREITAS, 2012. Immature stages of the Neotropical butterfly, Dynamine agacles agacles. Journal of Insect Science 12(37): 1-12.

LEMES, R., C. D. RITTER \& A. B. B. MORAIS, 2008. Borboletas (Lepidoptera: Hesperioidea e Papilionoidea): visitantes florais no Jardim Botânico da Universidade Federal de Santa Maria, Santa Maria, RS, Brasil. Biotemas 21(4): 91-98.

MILLER, J. S., 1987. Phylogenetic studies in the Papilioninae (Lepidoptera: Papilionidae). Bulletin of the American Museum of Natural History 186: 365-512.

MOSS, A. M., 1919. The papilios of Pará. Novitates Zoologicae 26: 295-319.

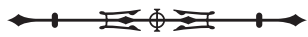


MOTTA, P. C., 2003. Phylogenetic relationships of Ithomiinae based on first-instar larvae. In: C. L. BOGGS, W. B. WATT \& P. R. EHRLICH (Eds.): Butterflies: ecology and evolution taking flight: 409-429. University of Chicago Press, Chicago.

O'HARA, J. E. \& D. M. WOOD, 2004. Catalogue of the Tachinidae (Diptera) of America North of Mexico: 1-410. Associated Publishers (Memoirs on Entomology, 18), Madison.

PAIM, A. C. \& R. A. DI MARE, 2002. Ecologia de Papilionidae. I: Parâmetros biológicos e demográficos de Parides agavus (Papilioninae: Troidini) no sul do Brasil. Biociências 10(2): 33-48.

PAIM, A. C., L. A. KAMINSKI \& G. R. P. MOREIRA, 2004. Morfologia externa dos estágios imaturos de heliconíneos neotropicais: IV. Dryas iulia alcionea (Lepidoptera: Nymphalidae, Heliconiinae). Iheringia. Série Zoologia 94(1): 25-35.

PANIZZI, A. R. \&J. R. P. PARRA (Orgs.), 1991. Ecologia nutricional de insetos e suas implicações no manejo de pragas: 1-359. Manole/ CNPq, São Paulo/Brasília.

PAZ, A. L. G., H. P. ROMANOWSKI \& A. B. B. MORAIS, 2008. Nymphalidae, Papilionidae e Pieridae (Lepidoptera: Papilionoidea) da Serra do Sudeste do Rio Grande do Sul, Brasil. Biota Neotropica 8(1): 141-149.

ROTHSCHILD, L. W. \& K. JORDAN, 1906. A revision of the American papilios. Novitates Zoologicae 13(3): 411-745.

SALGADO-NETO, G., 2010. Lepidópteros do Brasil (agenda de campo): 1-83. Rede de Inovação Tecnológica para Defesa Agropecuária, Viçosa.

SILVA, A. G. A., C. R. GONÇALVES, D. M. GALVÃO, A. J. L. GONÇALVES, J. GOMES, M. N. SILVA \& L. SIMONI, 1968. Quarto catálogo dos insetos que vivem nas plantas do Brasil: seus parasitos e predadores: 2(1): 1-622. Ministério da Agricultura, Rio de Janeiro.
SPECHT, M. J. S. \& M. PALUCH, 2009. Estágios imaturos de Caligo illioneus illioneus (Cramer) (Nymphalidae: Morphinae: Brassolini). Neotropical Entomology 38(6): 801-808.

STEFANESCU, C., 2004. Seasonal change in pupation behavior and pupal mortality in a swallowtail butterfly. Animal Biodiversity and Conservation 27(2): 25-36.

STEHR, F. W., 1987. Order Lepidoptera. In: F. W. STEHR (Ed.): Immature insects: 1: 288-596. Kendall Hunt Publishing Co., Dubuque.

TIGVATNANONT, S., 1995. Biological investigations on two butterflies, Graphium eurypylus Felder and G. Agamemnon L. (Lepidoptera: Papilionidae), and their host plant. King Mongkut's Agricultural Journal 13(1): 47-59.

TYLER, H. A., K. S. BROWN JR. \& K. H. WILSON, 1994. Swallowtail butterflies of the Americas: a study in biological dynamics, ecological diversity, biosystematics, and conservation: 1-376. Scientific Publishers, Gainesville.

VANE-WRIGHT, R. I., 2003. Evidence and identity in butterfly systematics. In: C. L. BOGGS, W. B. WATT \& P. R. EHRLICH (Eds.): Butterflies: ecology and evolution taking flight: 477-514. The University of Chicago Press, Chicago.

XIUSHAN, L., Z. YALIN, L. YOUQING \& J. SETTELE, 2006. Life history, life table, habitat, and conservation of Byasa impediens (Lepidoptera: Papilionidae). Acta Ecologica Sinica 26(10): $3184-$ 3197.

ZUCCHI, R. A., R. B. QUERINO \& R. C. MONTEIRO, 2010. Diversity and hosts of Trichogramma in the New World, with emphasis in South America. In: F. L. CÔNSOLI, J. R. P. PARRA \& R. A. ZUCCHI (Eds.): Egg parasitoids in agroecosystems with emphasis on Trichogramma: 219-236. Springer, Dordrecht.

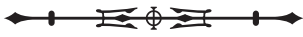


